\title{
KEBIJAKAN HUKUM PIDANA DALAM PEMBERANTASAN TINDAK PIDANA PENCUCIAN UANG DI INDONESIA
}

\author{
Riyanda Elsera Yozani \\ Universitas Riau, Indonesia, riyandayozani@yahoo.com
}

\begin{abstract}
Money laundering criminal acts are referred to as follow-up crimes and follow-up actions, money laundering is a follow-up action that is continued or an original crime (predicate crime) while the follow-up perpetrator of the findings of a large fund that appears to be clean or lawful, using sophisticated, creative and complex methods The purpose of deciding on this Test is, namely; First, the Current Criminal Law Policy Can Overcome Money Laundering in Indonesia, Secondly, Constraints that back down in the Criminal Law Policy in overcoming Money Laundering in Indonesia. This type of research can be classified in the type of Normative Law research. From the results of the study there are two main things that can be concluded. First, criminal law policy in the renewal of criminal law in the field of money laundering crimes that focuses on the policy formulation of criminal acts, criminal liability, and criminal sanctions In other words, renewal of criminal law requires the existence of research and thinking on a central problem and very fundamental and strategic in formulated in a statutory regulation. Criminal law policy in the framework of overcoming money laundering crimes can be formulated as an effort to make and form regulations on criminal law in the future effectively and efficiently. Second, Constraints in dealing with money laundering crimes in addition to the Constraints of the Financial Transaction Analysis Center (PPATK), Banking constraints, Police Investigator Constraints and lack of coordination between other law enforcement officers in carrying out money laundering and government efforts to overcome obstacles - these obstacles.
\end{abstract}

Keywords: Legal Policy - Eradication - Crime - Money Laundering

\section{ABSTRAK}

Tindak pidana pencucian uang disebut sebagai kejahatan yang bersifat ganda dan lanjutan (Follow Up Crime), karena tindak pidana pencucian uang merupakan suatu perbuatan yang diteruskan atau lanjutan dari tindak pidana asal (predicate crime) dimana si pelaku memproses sejumlah besar uang ilegal hasil tindak pidana menjadi dana yang kelihatannya bersih atau sah menurut hukum, dengan menggunakan metode yang canggih, kreatif dan kompleks. Tujuan penulisan Tesisi ini, yakni; Pertama, Kebijakan Hukum Pidana Yang Ada Sekarang Ini dapat Menanggulangi Tindak Pidana Pencucian Uang di Indonesia, Kedua, Kendala yang dihadapi dalam Kebijakan Hukum Pidana dalam menanggulangi Tindak Pidana Pencucian Uang di Indonesia. Jenis penelitian ini dapat digolongkan dalam jenis penelitian Hukum Normatif, Dari hasil penelitian ada dua hal pokok yang dapat disimpulkan. Pertama, Kebijakan hukum pidana dalam Pembaharuan hukum pidana di bidang kejahatan pencucian uang yang memfokuskan pada kebijakan perumusan perbuatan pidananya, pertanggungjawaban pidana, dan sanksi pidananya Dengan kata lain pembaharuan hukum pidana menuntut adanya penelitian dan pemikiran terhadap masalah yang sentral dan sangat fundamental dan stategis yang di formulasikan dalam suatu peraturan perundangundangan. Kebijakan hukum pidana dalam kerangka penanggulangan tindak pidana pencucian uang dapat dirumuskan sebagai upaya bagaimana membuat dan membentuk 
peraturan hukum pidana dimasa yang akan datang secara efektif dan berdaya guna. Kedua, Kendala dalam menangani Tindak pidana pencucian uang ini selain Kendala Pusat Pelapor Analisis Transaksi Keuangan (PPATK), kendala Perbankan, Kendala Penyidik Kepolisian dan kurangnya koordinasi antara aparat penegak hukum lainnya dalam menjalankan tindak pidana pencucian uang dan perlu dilakukannya upaya dari pemerintah untuk mengatasi kendala- kendala tersebut.

\section{Kata Kunci: Kebijakan Hukum - Pemberantasan - Tindak Pidana - Pencucian Uang}

\section{Latar Belakang}

Tindak pidana pencucian uang disebut sebagai kejahatan yang bersifat ganda dan lanjutan (Follow Up Crime), karena tindak pidana pencucian uang merupakan suatu perbuatan yang diteruskan atau lanjutan dari tindak pidana asal (predicate crime) dimana si pelaku memproses sejumlah besar uang ilegal hasil tindak pidana menjadi dana yang kelihatannya bersih atau sah menurut hukum, dengan menggunakan metode yang canggih, kreatif dan kompleks. Atau, tindak pidana pencucian uang sebagai suatu proses atau perbuatan yang bertujuan untuk menyembunyikan atau menyamarkan asal-usul tindak pidana melalui kegiatan menempatkan, mentransfer, mengalihkan, membelanjakan, membayar, menghibahkan, menitipkan, membawa keluar negeri, mengubah bentuk, menukarkan dengan mata uang atau surat berharga yang diperoleh dari hasil tindak pidana yang kemudian diubah menjadi harta kekayaan yang seolah-olah berasal dari kegiatan yang sah. ${ }^{1}$

Aktivitas pencucian uang berdampak pada sektor perekonomian maupun bisnis dengan cara merongrong sektor bisnis swasta yang sah, merongrong integritas pasar-pasar keuangan, mengakibatkan hilangnya kendali pemerintah terhadap kebijakan ekonomi serta menimbulkan distorsi

\footnotetext{
${ }^{1}$ Yunus Husein dan Roberts K, Tipologi dan Perkembangan Tindak Pidana Pencucian Uang, Raja Grafindo Persada, Jakarta, 2018, hlm. 14.
}

dan ketidakstabilan ekonomi. Kejahatan pencucian uang itu sangat potensial dalam mempengaruhi atau mengganggu perekonomian baik nasional maupun internasional karena membahayakan efektifitas operasi sistem perekonomian dan bisa pula menimbulkan kebijakan ekonomi yang buruk, terutama pada negara-negara tertentu. Praktik pencucian uang juga membuat ketidakstabilan pada ekonomi nasional karena pencucian uang juga dapat menyebabkan terjadinya fluktuasi yang tajam pada nilai tukar dan suku bung. $^{3}$

Upaya internasional untuk memberantas pencucian uang berangkat dari kegagalan dalam memberantas peredaran gelap narkotika dan sejenisnya. Upaya pemerintah untuk memberantas sudah dimulai sejak disahkannya Internasional Opium Convension of 1912, yang diikuti dengan 13 instrumen internasional lainnya dan berpuncak pada United Nations Convension Againts Illicit Traffic in Narcotic Drugs and Psyochotropic Substances, 1988 (Vienna Drugs Convension 1988). ${ }^{4}$

${ }^{2}$ Iwan Kurniawan, Perkembangan Tindak Pidana Pencucian Uang (Money Laundering) Dan Dampaknya Terhadap Sektor Ekonomi Dan Bisnis, Jurnal Ilmu Hukum, Volume 3, Nomor 1, 2013, hlm.11

${ }^{3}$ Bismar Nasution, Rejim Anti Pencucian uang di Indonesia, Books Terrace \& Library Pusat Informasi Hukum Indonesia, Bandung, 2005, hlm.1.

${ }^{4} \mathrm{M}$. Cherif Bassiouni, Internasional and National Control Drugs Trafficking Symposium:Critical Refelction on Control of 
Negara Indonesia meratifikasi peraturan pencucian uang untuk menghindari sanksi (counter measures) dari negara-negara yang tergabung dalam Financial Action Taks Force of Money Laundering (FATF) maka pada tahun 2002 tepatnya tanggal 17 April 2002 Indonesia mengundangkan Undang-Undang Nomor 15 Tahun 2002 tentang Tindak Pidana Pencucian Uang dan bersamaan didirikan Pusat Pelaporan dan Analisis Transaksi Keuangan (PPATK) yang mana merupakan lembaga independen yang di bentuk dalam rangka mencegah dan memberantas tindak pidana pencucian uang, karena apabila Indonesia belum meratifikasi Undang-undang tentang Tindak Pidana Pencucian uang maka akibatnya Indonesia akan di masukan kedalam daftar negara yang Non Cooperative Countries and Teritories (NCCTs) yang tentu saja hal ini akan membawa dampak negatif bagi Indonesia dalam perdagangan internasional. Undang-Undang Nomor 15 Tahun 2002 tentang Tindak Pidana Pencucian Uang, ini adalah bahwa perbuatan pencucian uang harus dicegah dan diberantas agar intensitas kejahatan yang menghasilkan atau melibatkan harta kekayaan yang jumlahnya besar dapat diminimalisasi sehingga stabilitas nasional dan keamanan negara terjaga. UndangUndang 15 Tahun 2002 tentang Tindak Pidana Pencucian Uang telah diundangkan namun belum mengeluarkan Indonesia dari Non Cooperative Countries and Teritories (NCCT's). ${ }^{5}$

Drugs, Den.J.Int'l \& Pol'l, vol.18:13, 1990, hlm .312 .

5 Pertimbangan Hukum Undang-Undang Nomor 15 Tahun 2002 Tentang Tindak Pidana Pencucian Uang kemudian diubah menjadi Undang-undang Nomor 25 Tahun 2005 tentang Tindak Pidana Pencucian Uang, dan selanjutnya diubah kembali menjadi Undang-Undang Nomor 8 Tahun 2010 tentang Pencegahan dan Pemberantasan Tindak pidana Pencucian Uang.
Pengesahan undang-undang ini tidak secara otomatis menghapus Indonesia dari daftar hitam Non Cooperative Countries and Teritories (NCCTs) Financial Action Taks Force of Money Laundering, dengan alasan Indonesia dianggap belum membuktikan adanya program penegakan hukum pencucian uang yang efektif. ${ }^{6}$

Setahun kemudian Dewan Perwakilan Rakyat Indonesia menyetujui Undang-Undang Nomor 25 Tahun 2003 tentang Tindak Pidana Pencucian Uang, dan pada Februari 2005 Indonesia keluar dari (Non Cooperative Countries and Teritories NCCT's), namun Indonesia masuk ke dalam fase monitoring dibawah pengawasan Tim Review Financial Action Taks Force of Money Laundering (FATF). ${ }^{7}$

Indonesia meamandemen untuk ke tiga kalinya yaitu Undang-Undang Nomor 8 Tahun 2010 tentang Pencegahan dan Pemberantasan Tindak Pidana Pencucian uang inilah merupakan ketiga kalinya Indonesia melakukan perubahan peraturan mengenai pencucian uang dan melalui Undang-Undang Nomor 8 Tahun 2010 ditetapkan legalitas pencucian uang sebagai tindak pidana (perbuatan kriminal). Kriminalisasi pencucian uang ini dipercepat oleh desakan International Monetary Fund (IMF) dan Financial Action Taks Force of Money Laundering (FATF) dimana Letter Of Intent antara IMF dan Indonesia mensyaratkan adanya undang- undang anti pencucian uang

\footnotetext{
${ }^{6}$ Supriyadi Widodo Eddyono dan Yonatan Iskandar Chandra, Mengurai Implementasi dan Tantangan Anti Pencucian Uang Indonesia, Institute for Criminal Justice Reform, Jakarta, 2015, hlm. 11.

${ }^{7}$ Tb. Imran, Hukum Pembuktian Pencucian Uang (Money Laundering), MSQ Publishing, Bandung, 2006, hlm. 2.
} 
sebagai prasyarat pencairan dana pinjaman. $^{8}$

Dalam perkembangannya, demi mendukung efektivitas dari UndangUndang Nomor 8 Tahun 2010 Tentang Pencegahan dan Pemberantasan Tindak Pidana Pencucian Uang, pemerintah akhirnya mengeluarkan Peraturan Pemerintah Nomor 43 Tahun 2015 Tentang Pihak Pelapor ${ }^{9}$ serta Surat Edaran Pusat Pelaporan dan Analisis Transaksi Keuangan (PPATK) Nomor: SE-03/1.02/PPATK/05/15 Tentang Indikator Transaksi Keuangan Mencurigakan Bagi Penyedia Jasa Keuangan. ${ }^{10}$

Tindak pidana pencucian uang dirasakan tidak pernah habis bahkan semakin banyak dan bahkan perkembangannya dari tahun ketahun semakin meningkat baik dalam kasus, jumlah kerugian negara maupun modus operandinya. Modus operandinya semakin tersistematis dan telah merambah ke berbagai kehidupan masyarakat dan lintas batas negara. Salah satunya berasal dari kejahatan hasil korupsi, dimana secara nasional korupsi disepakati tidak saja kejahatan luar biasa (extra ordinary crime) dan kejahatan transnasional.

Pencucian uang, dimana uang hasil kejahatan menjadi uang yang aman untuk digunakan harus dicegah dan diberantas. Salah satu kebijakan yang hendak digunakan adalah kebijakan Hukum Pidana. Tindak pidana pencucian ini sangat merugikan

\footnotetext{
http://fadjroelrahman2014 $\begin{array}{ll}\text {.wordpress.Com/tag /uu-nomor-8-tahun-2010- } & \text { dentang-tindak-pidana-pencucian-uang/ diakses }\end{array}$ tanggal 12 September 2018, 10.43 Wib, hlm. 6.

${ }^{9}$ http://en.hukumonline.com/ pages/ lt5 59df $42 a 630 f 9$ pemerintah- perluas- pelapor- tindakpidanapencucian-uang, diakses tanggal 23 October 2018, 02.38 Wib.

Surat Edaran Nomor : SE03/1.02/PPATK/05/15 Tentang Indikator Transaksi Keuangan Mencurigakan Bagi Penyedia Jasa Keuangan, Pusat Pelaporan dan Analisis Transaksi Keuangan.
}

bagi kehidupan berbangsa dan bernegara, serta mengganggu stabilitas perekonomian indonesia. Pemerintah selaku penyelenggara kehidupan berbangsa dan bernegara perlu memberikan perlindungan bagi kesejahteraan masyarakat melalui kebijakan pemerintah yang tergabung dalam kebijakan sosial (social policy). Kebijakan sosial dapat berupa kebijakan dibidang politik, ekonomi, hukum, perpajakan, pertahanan keamanan, pengelolaan sumber daya alam, perumahan yang layak, kesehatan yang layak, kesehatan lingkungan dan sebagainya, yang berpengaruh pada peningkatan kualitas kehidupan masyarakat. $^{11}$

Berdasarkan latar belakang diatas, menarik untuk diteliti dan dilakukan penelitian dengan judul "Kebijakan Hukum Pidana dalam Pemberantasan Tindak Pidana Pencucian Uang di Indonesia"

\section{Rumusan Masalah}

1. Apakah Kebijakan Hukum Pidana Yang Ada Sekarang Ini dapat Menanggulangi Tindak Pidana Pencucian Uang di Indonesia?

2. Bagaimana Kendala yang dihadapi dalam Kebijakan Hukum Pidana dalam menanggulangi Tindak Pidana Pencucian Uang di Indonesia

\section{Metode Penelitian}

Jenis penelitian ini menggunakan pendekatan hukum normatif.

\section{Hasil Penelitian Dan Pembahasan}

\section{Kebijakan Hukum Pidana Yang Ada Sekarang Ini dapat Menanggulangi Tindak Pidana Pencucian Uang di Indonesia}

${ }^{11}$ Diana M.Dinitto, Sosial Welfare, Politics and Public Policy, Allyn \& Bacon, Boston, 2000, hal. 2. Dalam Artikel Mahmud Mulyadi, Penanggulangan Tindak Pidana Korupsi Dalam Perspektif Criminal Policy, 2013, hlm 4. 
Kebijakan hukum pidana atau disebut juga dengal "Penal Policy" adalah suatu ilmu sekaligus seni yang pada akhirnya mempunyai tujuan praktis untuk memungkinkan peraturan hukum positif dirumuskan secara lebih baik dan untuk memberi pedoman tidak hanya kepada pembuat undangundang. Tetapi juga kepada kepada pengadilan yang menerapkan undangundang dan juga kepada para penyelenggara atau pelaksana putusan pengadilan. ${ }^{12}$

Pemerintah Indonesia bersama dengan Dewan Perwakilan Rakyat dalam rangka penanggulangan kejahatan money laundering telah membentuk beberapa produk hukum untuk menangani persoalan pencucian uang diantaranya Undang-Undang Nomor 15 Tahun 2002 yang telah diubah dengan Undang-Undang Nomor 25 Tahun 2003 tentang Tindak Pidana Pencucian Uang, dan terakhir diubah dengan Undang-Undang Nomor 8 Tahun 2010 tentang Pencegahan dan Pemberantasan Tindak Pidana Pencucian Uang.

a) Pencucian Uang di Indonesia dalam Undang-Undang Nomor 8 Tahun 2010 Tentang Pencegahan dan Pemberantasan Tindak Pidana Pencucian Uang

\section{Bentuk-Bentuk Tindak Pidana Pencucian Uang}

Tindak Pidana Pencucian Uang yang diatur dalam UndangUndang Nomor 8 Tahun 2010 tentang Pencegahan dan Pemberantasan Tindak Pidana Pencucian Uang, dapat dikelompokkan menjadi 2 (dua) jenis, yaitu : Tindak Pidana Pencucian Uang Aktif dan Tindak Pidana Pencucian Uang Pasif. Secara singkat, Tindak Pidana Pencucian Uang Aktif dapat diartikan sebagaimana perbuatan

\footnotetext{
${ }^{12}$ Barda Nawawi Arif, Op.cit, hlm.23.
}

yang diatur dalam Pasal 3 dan Pasal 4, yaitu kegiatan yang aktif dilakukan dalam rangka menyembunyikan asal-usul harta kekayaan hasil tindak pidana. Tindak Pidana Pencucian Uang Pasif dapat diartikan sebagaimana perbuatan yang diatur dalam Pasal 5, yaitu kegiatan pasif berupa perbuatan menerima atau menguasai pentransferan harta kekayaan hasil tindak pidana.

\section{Penentuan Predicate Crime dalam Tindak pidana Pencucian Uang}

Tindak pidana asal (predicate crime) tidak benerbenar harus ada, cukup dengan patut diduga saja bahwa sebelumnya telah terjadi tindak pidana asal (predicate crime) yang menghasilkan harta kekayaan yang kemudian "dicuci" maka tindak pidana pencucuian uang telah terbukti terjadi. Tindak pidana asal (predicate crime) tidak benar benar harus menjadi causa (sebab) terjadinya tindak pidana pencucian uang. ${ }^{13}$

3. Sistem Pembuktian dalam Undang-Undang Tindak Pidana Pencucian Uang

Perkembangan sistem hukum pembuktian berkembang dengan diundangkannya UndangUndang Nomor 31 Tahun 1999 jo Undang-Undang Nomor 20 Tahun 2001 atau Undang-Undang Anti Korupsi, yang menganut Sistem Pembuktian Terbalik Seimbang. Di dalam undangundang Anti Korupsi tersebut, dijelaskan bahwa Tersangka/ Terdakwa wajib membuktikan asal usul harta kekayaannya, namun jika tidak mampu

${ }^{13}$ Yunus Husein dan Roberts K, Op.Cit, hlm. 15-16. 
membuktikan maka tidak serta merta menjadi bersalah, karena Jaksa Penuntut Umum (JPU) pun wajib membuktikan asal usul harta kekayaan dari Terdakwa tersebut. $^{14}$

Ketentuan tersebut dianut pula dalam the second regime anti- money laundering, sebagaimana disebutkan dalam Pasal 77 Undang-Undang Nomor 8 Tahun 2010 tentang Pencegahan dan Pemberantasan Tindak Pidana Pencucian Uang yaitu sebagai berikut: Untuk kepentingan pemeriksaan di sidang pengadilan, terdakwa wajib membuktikan bahwa Harta Kekayaannya bukan merupakan hasil tindak pidana.

\section{Penyitaan Harta Kekayaan}

Di dalam regime antimoney laundering, terdapat ketentuan yang memberikan kewenangan bagi Penyidik dan Pengadilan untuk melakukan penyitaan terhadap harta kekayaan yang diduga sebagai proceeds of crime.

5. Pemeriksaan Secara In

$\begin{array}{llr}\text { Absentia } & \text { Dalam } & \text { Undang- } \\ \text { Undang } & \text { Tindak } & \text { Pidana } \\ \text { Pencucian Uang } & \end{array}$

Di dalam perumusan Pasal 79 ayat (1) Undang-Undang Nomor 8 Tahun 2010 tentang Pencegahan dan Pemberantasan Tindak Pidana Pencucian Uang tersebut ditentukan bahwa terdakwa harus terlebih dahulu secara patut dan layak, namun jika terdakwa tetap tidak menghadiri pemeriksaan persidangan tanpa alasan yang sah, maka pemeriksaan dilanjutkan. Perumusan tersebut telah sesuai dengan ketentuan

${ }^{14}$ Lihat Pasal 37 Undang-Undang Nomor 31 Tahun 1999 tentang hak terdakwa melakukan pembuktian dalam harta benda yang dimilikinya.
Pasal 214 ayat (1) Kitab UndangUndang Hukum Acara Pidana.

6. Perumusan Sistem Pemidanaan dalam Undang-Undang Tindak Pidana Pencucian Uang.

Undang-undang Tindak Pidana Korupsi ini jelas lebih memiliki bobot dalam perumusan pasal-pasal pemidanaannya dibandingkan Undang-undang money laundering. Dengan model perumusan seperti dalam Undangundang Anti-money laundering justru menimbulkan putusan yang sangat rendah pemidanaannya.

Penggantian pidana denda menjadi pidana kurungan sangat tidak seimbang. Sehingga seorang terpidana akan lebih memilih pidana kurungan dari pada diwajibkan membayar denda. Sebagai sebuah Undang-undang yang mengedepankan pemidanaan pidana penjara, jika diperhatikan pidana kurungan pengganti pidana denda, sangat jauh dari kepantasan. ${ }^{15}$

7. Kewenangan Pusat Pelaporan dan Analisis Transaksi Keuangan dalam proses penangan Tindak Pidana Pencucian Uang

Dalam Pasal 65 ayat (1) Undang-Undang Nomor 8 Tahun 2010 tentang Pencegahan dan Pemberantasan Tindak Pidana Pencucian Uang yang menegaskan sebagai berikut: "Pusat Pelaporan dan Analisis Transaksi Keuangan (PPATK) dapat meminta penyedia jasa keuangan untuk menghentikan sementara seluruh atau sebagian Transaksi sebagaimana dimaksud dalam Pasal 44 ayat (1) huruf i." Pasal ini berpotensi melanggar kepentingan hukum dari pihakpihak yang sedang melakukan

\footnotetext{
${ }^{15}$ Ibid.
} 
transaksi untuk kepentingan usahanya. Keberadaan pasal ini dapat dijadikan alat penekan dari institusi secara illegal, sehingga Pusat Pelaporan dan Analisis Transaksi Keuangan (PPATK) harus meminta Penetapan dari Pengadilan Negeri terlebih dahulu, dengan memeriksa buktibukti yang cukup tersebut untuk menghentikan sementara suatu transaksi. Sehingga demi melindungi kepentingan kas keuangan negara namun juga tidak melanggar hak warga negara dalam melakukan usaha. ${ }^{16}$

Pusat Pelaporan dan Analisis Transaksi Keuangan (PPATK) bukan lembaga eksekutif yang bertugas untuk mengeksekusi, bahkan Kejaksaan untuk mengeksekusi saja membutuhkan putusan pengadilan yang telah inkracht. Pasal tersebut justru menimbulkan ketidakseimbangan, bahwa penyidik, penuntut dan hakim memiliki tingkatan yang lebih rendah dari pada Pusat Pelaporan dan Analisis Transaksi Keuangan (PPATK). Karena ketiga lembaga tersebut adalah institusi penegak hukum, sedangkan Pusat Pelaporan dan Analisis Transaksi Keuangan (PPATK) hanya lembaga yang berfungsi sebagai pendukung dari institusi penegak hukum yang ada (supporting institution). ${ }^{17}$

b) Kebijakan Pemerintah Indonesia dan Bank Indonesia dalam Menanggulangi Pencegahan dan Pemberantasan Tindak Pidana Pencucian Uang di Indonesia

16 Kebijakan Formulasi http://yehezkielkristian .blogspot .com /2012/ 02/ kebijakan formulasi- hukum-pidana.html. Diakses pada tanggal 03 November 2013 Pukul 12.22

${ }^{17}$ Ibid

\section{Kebijakan Pemerintah Republik Indonesia}

Pencegahan

dari

pemberantasan kegiatan money laundering dapat dilakukan melalui pendekatan pidana atau pendekatan bukan pidana, seperti pengaturan dan tindakan administratif. Partisipasi Pemerintah Republik Indonesia dalam upaya pemberantasan kegiatan pencucian uang merupakan pelaksanaan dari amanat Perserikatan BangsaBangsa dalam the UN Convention Against Illicit Traffic in Narcotics, Drugs and Psychotropic Substances of 1988 yang kemudian diratifikasi oleh Pemerintah melalui UndangUndang Nomor 7 Tahun 1997 tentang Pengesahan United Nations Convention Against Illicit Traffic in Narcotics, Drugs and Psychotropic Substances of 1988 (Konvensi Perserikatan Bangsa Bangsa Tentang Pemberantasan Peredaran Gelap Narkotika dan Psikotropika, 1998. Dengan penandatanganan konvensi tersebut maka setiap negara penandatangan diharuskan untuk menetapkan kegiatan pencucian uang sebagai suatu tindak pidana dan mengambil langkah-Iangkah agar pihak yang berwajib dapat mengindentifikasikan, melacak dan membekukan atau menyita hasil perdagangan obat bius. ${ }^{18}$

\section{Kebijakan Bank Indonesia} Terdapat beberapa ketentuan yang dikeluarkan oleh Bank Indonesia yang secara langsung atau tidak langsung dapat mencegah, mengurangi atau

${ }^{18}$ https://yunushusein. files. Word press. com/2007/ 07 /27_ kebijakan -ban kindonesia_yh_x.pdf di askes tanggal 13 November 2018 Pukul 5:45 WIB 
memberantas kegiatan money laundering secara administratif. Khusus ketentuan BI (Bank Indonesia) yang dikeluarkan untuk mencegah kegiatan pencucian uang yang sejalan dengan rekomendasi dari Financial Action Taks Force of Money Laundering (FATF) dan Basle Committee on Banking Supervision adalah Peraturan Bank Indonesia No. 3/10/PBI/2001 tentang Penerapan Prinsip Mengenal Nasabah (Know Your Customer Principles) sebagaimana telah diubah dengan Peraturan Bank Indonesia No. 3/23/PBI/2001 tentang Perubahan Atas PBI No. 3/10/PBI/2001 tentang Penerapan Prinsip Mengenal Nasabah (Know Your Customer Principles). ${ }^{19}$

A. Kendala yang dihadapi dalam Kebijakan Hukum Pidana dalam menanggulangi Tindak Pidana Pencucian Uang di Indonesia

1. Semakin Meningkatnya Money Laundering

Saat ini pelaku tindak kejahatan mempunyai banyak pilihan mengenai di mana dan bagaimana mereka menginginkan uang hasil kejahatan menjadi kelihatan "bersih" dan "sah menurut hukum". Perkembangan teknologi perbankan internasional yang telah memberikan jalan bagi tumbuhnya jaringan perbankan lokal/ regional menjadi suatu lembaga keuangan global telah memberikan kesempatan kepada pelaku money laundering dalam memanfaatkan jaringan layanan tersebut yang berdampak uang

${ }^{19}$ https://yunushusein. files. Word press. com/2007/ 07 /27_ kebijakan -ban kindonesia_yh_x.pdf di askes tanggal 13 November 2018 Pukul 5:45 WIB hasil transaksi ilegal menjadi legal dalam dunia bisnis di pasar keuangan internasional. Saat ini kegiatan pencucian uang telah melewati batas juridiksi yang menawarkan tingkat kerahasiaan yang tinggi atau menggunakan bermacam mekanisme keuangan dimana uang dapat 'bergerak' melalui bank, money transmitters, kegiatan usaha bahkan dapat dikirim ke luar negeri sehingga menjadi clean laundered money. ${ }^{20}$

2. Kendala Pusat Pelaporan dan Analisis Transaksi Keuangan (PPATK) dalam Mencegah dan Memberantas tindak pidana pencucian Uang

Didalam pelaksanaan fungsi, tugas, wewenangnya, Pusat Pelaporan dan Analisis Transaksi Keuangan (PPATK) masih menghadapi beberapa hambatan seperti:

1) Keterbatasan sumber informasi yang berasal dari Penyedia Jasa Keuangan (PJK) berupa laporan Transaksi Keuangan Mencurigakan (LKTM) dan atau Laporan Transaksi Keuangan Tunai (LTKT);

2) Keakuratan data nasabah baik yang tercantum di dalam Laporan Transaksi Keuangan (LTKM) maupun Laporan Transaksi Keuangan Tunai (LTKT) yang dilaporkan kepada Pusat Pelaporan dan Analisis Transaksi Keuangan (PPATK);

3) Banyaknya Interprestasi yang berbeda antara pihak aparat penegak hukum, Penyedia Jasa Keuangan (PJK), serta akademisi;

4) Keterbatasan sistem teknologi informasi Penyedia Jasa Keuangan (PJK) terkait dengan 
Laporan Transaksi Keuangan (LTKM) dan atau Laporan Transaksi Keuangan Tunai (LTKT) secara online. ${ }^{21}$

\section{Kendala yang dihadapi oleh} Perbankan

Dalam hal lain yang menjadi kendala perbankan dalam mencegah dan memberantas tindak pidana pencucian uang adalah: ${ }^{22}$

a. Sulitnya mendapatkan identitas yang sebenarnya dari nasabah, kegiatan menjalankan prinsip pengenalan penggunaan jasa dapat menyebabkan nasabah menarik dananya atau tidak jadi menggunakan jasa lembaga perbankan karena dianggap melnggar privasi dari nasabah tersebut;

b. Penggunaan identitas palsu oleh pengguna jasa untuk mengelabui bank untuk menggunakan jasa lembaga perbankan untuk tindak pidana pencucian uang dan tindak pidana lainnya;

c. Rendahnya profesionalitas pegawai yang dimiiki bank sehingga tidak paham dengan kewajibannya dalam menerapkan program anti pencucian uang oleh perbankan.

d. Teknologi informasi yang dimiliki bank masih belum memiliki jaringan online yang cukup memadai sehingga pelaporan transaksi harus dilakukan secara manual yang

${ }^{21}$ David Ramadhan, Penegakan Hukum terhadap pelaku dalam rezim Tindak Pidana Pencucian Uang di Indonesia, Disertasi, Fakultas Hukum Universitas Andalas, Padang, 2018, hlm.43

${ }^{22}$ Shirlsy, Santosa, Analisis Perbandingan PPATK (Pusat Pelaporan Analisi Transaksi keuangan) di Indonesia dengan FinCEN (Financial Crimes Enforcement Network) di Amerika Serikat, Tesis, Progra Pasca Sarjana, Universitas Indonesia, Depok, 2011, hlm.85. akan menghabiskan waktu yang banyak.

4. Kendala yang dihadapi Penyidik Kepolisian dalam Mencegah dan Memberantas tindak Pidana Pencucian Uang

Bahwa pelaksanaan undangundang Tindak Pidana Pencucian Uang belum berjalan dengan efektif, utamanya karenanya pemahaman oleh pihak-pihak terkait dalam proses penegakan hukumnya atas beberapa ketentuanketentuan yang ada dalam undangundang tindak pidana pencucian uang masih beragam. Sebagai contoh, mengenai pemblokiran dan permintaan keterangan atas harta kekayaan nasabah, belum ada standarisasi format suratnya sehingga dalam pelaksanaannya seringkali menjadi tidak efektif. ${ }^{23}$

\section{Kesimpulan}

1. Kebijakan hukum pidana dalam Undang-Undang Nomor 8 Tahun 2010 tentang Pencegahan dan Pemberantasan tindak pidana Pencucian Uang merupakan sebuah tindak pidana kejahatan yang mana hendak di atur. Di Indonesia sendiri Tindak Pidana Pencucian Uang telah 3 (tiga) kali mengalami perubahan, ada pun Undang-Undang yang mengatur tentang Tindak Pidana Pencucian Uang, yakni : UndangUndang Nomor 15 tahun 2002 tentang Tindak pidana Pencucian Uang, Undang-Undang Nomor 25 Tahun 2003 tentang Tindak Pidana Pencucian Uang, dan UndangUndang Nomor 8 Tahun 2010 tentang Pencegahan dan Pemberantasan Tindak Pidana Pencucian Uang. Pembaharuan hukum pidana di bidang kejahatan

${ }^{23}$ Disertasi David Ramadhan, Op. Cit, hlm. 44 
pencucian uang yang memfokuskan pada kebijakan perumusan perbuatan pidananya, pertanggungjawaban pidana, dan sanksi pidananya Dengan kata lain pembaharuan hukum pidana menuntut adanya penelitian dan pemikiran terhadap masalah yang sentral dan sangat fundamental dan stategis yang di formulasikan dalam suatu peraturan perundang-undangan. Kebijakan hukum pidana dalam kerangka penanggulangan tindak pidana pencucian uang dapat dirumuskan sebagai upaya bagaimana membuat dan membentuk peraturan hukum pidana dimasa yang akan datang secara efektif dan berdaya guna. Kebijakan formulasi merupakan langkah awal didalam penanggulangan kejahatan yang secara fungsional dapat dilihat sebagai bagian dari perencanaan dan mekanisme penanggulangan kejahatan yang dituangkan kedalam perundang-undangan. Setelah dilakukanya kebijakan formulasi, maka dikukanlah Kebijakan Pemerintah Indonesia dan Bank Indonesia dalam Menanggulangi Pencegahan dan Pemberantasan Tindak Pidana Pencucian Uang di Indonesia.

2. Kendala yang dihadapi dalam penerapan kebijakan hukum pidana terhadap penanggulangan money laundering dalam rangka pembaharuan hukum pidana di Indonesia dan bagaimana upaya dalam mengatasinya. Kejahatan money laundering semakin meningkat dan efeknya sangat besar tidak hanya merupakan permasalahan di bidang penegakan hukum, namun juga menyangkut ancaman keamanan nasional dan internasional suatu negara, kendala dalam menangani Tindak pidana pencucian uang ini selain Kendala Pusat Pelapor Analisis Transaksi

\begin{abstract}
Keuangan (PPATK), kendala Perbankan, Kendala Penyidik Kepolisian dan kurangnya koordinasi antara aparat penegak hukum lainnya dalam menjalankan tindak pidana pencucian uang dan perlu dilakukannya upaya dari pemerintah untuk mengatasi kendala- kendala tersebut. Dalam menjalankan peranannya masingmasing dibutuhkan sinergi antar lembaga tersebut untuk mencegah dan memberantas tindak pidana pencucian uang yang berlaku secara efektif.
\end{abstract}

\section{Saran}

Berdasarkan kesimpulan di atas, maka penulis menarik menyarankan sebagai berikut:

1. Diharapkan kepada Pemerintah dalam melakukan Perumusan Peraturan Perundang-undangan Khususnya kedepannya agar lebih memperhatikan peraturan yang lebih umum sehingga tidak terjadi kerancuan makna dalam undangundang. Dalam peraturan pencucian uang, diharapkan pemerintah lebih tegas dalam merumuskan perbuatan pidana, pertanggungjawaban pidana, sanksi ataupun pemidanaan agar pelaku tindak pidana pencucian uang merasa lebih takut, hal ini guna mengurangi tindak pidana pencucian uang kedepannya.

2. Diharapkan bank memberlakukan sistem single Idenity number (nomor identitas tunggal) sehingga memudahkan bank dalam memperoleh identitas dari pengguna jasa dan menghindari pengguna identitas palsu untuk digunakan dengan tujun melakukan pencucian uang. Setiap pihak yang berperan dalam mencegah dan memberantas tindak pidana pencucian uang perlu meningkatkan kualitas dan koordinasi dengan antar instansi penegak hukum lainnya sehingga 
rezim anti pencucian uang di Indonesia akan berjalan secara efektif dan efisien. Terutama kepada kepolisisan yang memperlakukan keahlian khusus karena tindak pidana pencucian uang sama dengan tindak pidana konvensional lainnya, oleh karena itu membutuhkan keahlian khusus terutama untuk Kepolisian dalam menangani tindak pidana pencucian uang.

\section{Daftar Pustaka}

\section{A. Buku}

Arief, Barda Nawawi, 2008, Bunga Rampai Kebijakan Hukum Pidana (Perkembangan Penyusunan Konsep KUHP Baru), Kencana, Jakarta.

Eddyono, Supriyadi Widodo dan Yonatan Iskandar Chandra, 2015, Mengurai Implementasi dan Tantangan Anti Pencucian Uang Indonesia, Institute for Criminal Justice Reform, Jakarta.

Effendi, Erdianto, 2011, Hukum Pidana Indonesia, PT.Refika Aditama, Bandung.

Huda, Chiarul, 2008, Dari 'Tiada Pidana Tanpa Kesalahan' Menuju Kepada 'Tiada Pertanggungjawaban Pidana Tanpa Kesalahan', Kencana Prenada Media Grup, Jakarta.

Husein, Yunus dan Roberts K, 2018, Tipologi dan Perkembangan Tindak Pidana Pencucian Uang, Raja Grafindo Persada, Jakarta.

Imran, Tb. , 2006, Hukum Pembuktian Pencucian Uang (Money Laundering), MSQ Publishing, Bandung.
M.D, Moh, Mahfud, 1999, Pergulatan Politik dan Hukum di Indonesia, Gama Media, Yogyakarta.

Nasution, Bismar, 2005, Rejim Anti Pencucian uang di Indonesia, Books Terrace \& Library Pusat Informasi Hukum Indonesia, Bandung.

Purbacaraka, Purnadi, 1977, Penegakan Hukum Dalam Mensukseskan Pembangunan, Alumni, Bandung.

Rahardjo, Satjipto, 2010, Penegakan Hukum Progresif, Buku Kompas, Jakarta.

Soekanto Soerjono,2008, Faktor-Faktor yang Mempengaruhi Penegakan Hukum, PT Raja Grafindo, Jakarta.

2008, Pengantar Penelitian Hukum, Universitas Indonesia Press, Jakarta.

Sunggono, Bambang, 2003, Metodologi Penelitian Hukum, Raja Grafindo Persada, Jakarta.

\section{B. Jurnal}

Departemen Pendidikan dan Kebudayaan, Kamus Besar Bahasa Indonesia, Balai Pustaka, 1997.

David Ramadhan, Penegakan Hukum terhadap pelaku dalam rezim Tindak Pidana Pencucian Uang di Indonesia, Disertasi, Fakultas Hukum Universitas Andalas, Padang, 2018.

Diana M.Dinitto, 2013, Sosial Welfare, Politics and Public Policy, Allyn \& Bacon, Boston, 2000, hal. 2. Dalam Artikel Mahmud 
Mulyadi, Penanggulangan

Tindak Pidana Korupsi Dalam

Perspektif Criminal Policy.

Erdiansyah, 2012, "Penerapan Prinsip

Mengenal Nasabah Sebagai

Bentuk Peranan Bank Dalam

Mengantisipasi Tindak Pidana

Pencucian Uang (money

laundering)", Jurnal Ilmu

Hukum, Fakultas Hukum

Universitas Riau, Vol.3, No.1.

Kurniawan, Iwan, 2013, Perkembangan

Tindak Pidana Pencucian Uang

(Money Laundering) Dan

Dampaknya Terhadap Sektor

Ekonomi Dan Bisnis, Jurnal

Ilmu Hukum, Volume 3, Nomor 1.

Shirlsy, Santosa, 2011, Analisis Perbandingan PPATK (Pusat Pelaporan Analisi Transaksi keuangan) di Indonesia dengan FinCEN (Financial Crimes Enforcement Network) di Amerika Serikat, Tesis, Progra Pasca Sarjana, Universitas Indonesia, Depok.

\section{Website}

http:// fadjroelrahman 2014 . wordpress. Com/tag/ uu- nomor -8 -tahun 2010- tentang- tindak- pidanapencucian -uang/ diakses tanggal 12 September 2018.

http://en. Hukum online .com /pages/ lt559df42a630f9/pemerintahperluas- pelapor- tindak-pidana pencucian- uang, diakses tanggal 23 October 2018.

Kebijakan Formulasi http://yehezkielkristian. Blogspot .com/ 2012/ 02/ kebijakan formulasi- hukumpidana.html. Diakses pada tanggal 03 November Pukul 12.22

\section{Perundang-Undangan}

Kitab Undang-Undang Hukum Pidana.

Kitab Undang-Undang Hukum Acara Pidana.

Undang-Undang Nomor 8 Tahun 2010 tentang Pencegahan dan Pemberantasan Tindak Pidana Pencucian Uang, Lembaran Negara Repubik Indonesia Tahun 2010 Nomor 122, Tambahan Lembaran Negara Republik Indonesia Nomor 5164.

Undang-Undang Nomor 10 Tahun 1998 tentang Perbankan.

Undang-Undang Nomor 31 Tahun 1999 Jo. Undang-Undang Nomor 20 Tahun $2001 \quad$ Tentang Pemberantasan Tindak Pidana Korupsi.

Undang-Undang Nomor 39 Tahun 1999 Tentang Hak Asasi Manusia.

Undang-Undang No. 24 Tahun 1999 Tentang Lalu Lintas Devisa dan Sistem Nilai Tukar.

Peraturan Bank indonesia No 14/23/PBI/2013 tentang transfer dana serta Surat

Peraturan Bank Indonesia Nomor 3/10/2001 Tentang Penerapan Prinsip Mengenal Nasabah (Know YourCustomer Principles).

Surat Edaran Nomor : SE03/1.02/PPATK/05/15 Tentang Indikator Transaksi Keuangan Mencurigakan Bagi Penyedia Jasa Keuangan, Pusat Pelaporan dan Analisis Transaksi Keuangan. 
